\title{
Tingkat pengetahuan ibu memengaruhi keberhasilan toilet training pada anak prasekolah
}

\author{
Anestasia Pangestu Mei Tyas ${ }^{1 *}$, Yunita Yunita ${ }^{2}$, Amellia Mardhika $^{3}$, Lailatul Fadliyah ${ }^{4}$, Joko Susanto ${ }^{5}$ \\ $1,2,3,4,5$ Fakultas Vokasi, Universitas Airlangga, Indonesia \\ ${ }^{3,5}$ Fakultas Keperawatan, Universitas Airlangga, Indonesia \\ ${ }^{*}$ Coressponding Author : anestasia.pangestu@vokasi.unair.ac.id
}

\begin{abstract}
Abstrak
Pendahuluan: Tugas perkembangan kemandirian anak pada usia toddler dapat dilatih dengan toilet training. Faktanya pada anak prasekolah masih ada yang anak yang belum siap dan belum berhasil melakukan toilet training. Hasil studi pendahuluan salah satu TK di Lamongan menunjukkan sebagian kecil anak prasekolah masih mengompol dan memakai pampers saat malam hari. Penelitian ini bertujuan untuk menganalisis hubungan tingkat pengetahuan ibu dengan keberhasilan toilet training pada anak prasekolah. Metode: Penelitian cross sectional dengan jumlah sampel 40 responden memakai teknik simple random sampling. Pengumpulan data menggunakan kuesioner tingkat pengetahuan ibu dan kuesioner keberhasilan anak dalam toilet training. Analisa data meliputi univariat dan uji fishers exact test ( $p$ value $<0.05$ ). Hasil: Penelitian menyebutkan adanya hubungan antara tingkat pengetahuan ibu dengan keberhasilan toilet training pada anak prasekolah $(p$ value $=0.013$ ). Simpulan: Perlu adanya pendidikan kesehatan dari puskesmas dan dinas pendidikan tentang toilet training kepada orang tua untuk meningkatkan kesiapan dan keberhasilan toilet training.
\end{abstract}

Kata kunci: Pengetahuan ibu; prasekolah; toilet training

\section{Mother's level of knowledge affected the Success of toilet training in preschool children}

\begin{abstract}
Introduction: The task of developing the independence of children at toddler age can be trained by toilet training. The fact is that there are still some preschoolers who are not ready and have not succeeded in doing toilet training. The results of a preliminary study of a kindergarten in Lamongan showed a small proportion of preschool children still wet the bed and wore pampers at night. This study aims to analyze the relationship between the mother's level of knowledge and the success of toilet training in preschool children. Methods: This study was cross-sectional with a sample size of 40 respondents using a simple random sampling technique. The data were collected using a questionnaire on the level of maternal knowledge and a questionnaire on children's success in toilet training. Data analysis included univariate and fishers exact test ( $p$-value $<0.05)$. Results: The results showed a relationship between the mother's level of knowledge and the success of toilet training in preschool children ( $p$-value $=0.013$ ). Conclusions: There is a need for health education from health centers and education offices about toilet training for parents to improve the readiness and success of toilet training.
\end{abstract}

Keywords: Mother's knowledge; preschool; toilet training

How to Cite: Tyas, APM., Yunita, Y., Mardhika, A., Fadliyah, L., \& Susanto, J. (2021). Tingkat pengetahuan ibu memengaruhi keberhasilan toilet training pada anak prasekolah. NURSCOPE: Jurnal Penelitian dan Pemikiran IImiah Keperawatan, 7 (1), 38-44

\section{PENDAHULUAN}


Toilet training menjadi tugas perkembangan kemandirian anak pada usia $18-24$ bulan yang perlu mendapat perhatian dari orang tua yakni melatih kemampuan balita dalam mengendalikan buang air besar/kecil, sekaligus mempelajari anatomi dan fungsi tubuh (Hidayat, 2005). Keberhasilan dapat diketahui pada usia 5 tahun namun faktanya pada anak prasekolah masih terdapat ketidaksiapan dan ketidakberhasilan dalam melakukan toilet training (Utami et al., 2018).

Kesiapan fisiologis dan psikologis anak dalam toilet training tidak hanya berhenti sampai usia 24-30 bulan (Rogers, 2013), akan tetapi orang tua harus mulai mempersiapkan anak mereka untuk toilet training lebih awal. Toilet training pada anak tidak ada patokan usia yang tepat untuk memulai atau batas waktu untuk menyelesaikan toilet training (Hockenberry et al., 2017). Dibutuhkan kesiapan orang tua dan anak. Meskipun menunggu kesiapan anak, akan tetapi penelitian lain menyebutkan bahwa waktu optimal untuk memulai toilet training sebelum usia 24 bulan jika latihan dimulai setelah usia 24 bulan atau lebih, hal itu dapat menyebabkan peningkatan prevalensi disfungsi lower urinary tract (Li et al., 2020).

Sekitar 75 juta anak anak prasekolah di Indonesia belum mampu mengendalikan defekasi maupun miksi, berikut dituangkan dalam Survei Kesehatan Rumah Tangga Nasional (SKRT). Ketidakmampuan ini bisa saja dipengaruhi oleh beberapa faktor yakni kurangnya pengetahuan ibu, meningkatkan pemakaian popok sekali pakai, sibling rivalry, dan lain-lain (Fithriyana \& Aldopi, 2018). Pada anak usia prasekolah terdapat sebagian besar anak memiliki kemampuan cukup dan sebagian kecil sangat baik dalam toilet training di RA Perwanida 3 Sukoanyar Turi (Maghfuroh, 2017). Penelitian lain menunjukkan hampir setengah anak usia 5 tahun berhasil toilet training dan hampir setengahnya lagi gagal toilet training (Youstiana Dwi Rusita, 2015). Hasil studi pendahuluan salah satu TK di Lamongan didapatkan data jumlah anak prasekolah sebanyak 44 anak. Peneliti melakukan wawancara pada 10 orang tua yang anaknya berusia 4-6 tahun, diketahui sebagian kecil (20\%) orang tua berkata kalau anak mereka masih mengompol pada malam hari, sebagian kecil (10\%) menggunakan pampers, serta sebagian besar $(70 \%)$ anak sudah bisa ke toilet sendiri.

Salah satu faktor yang mempengaruhi keberhasilan toilet training adalah pengetahuan ibu. Pengetahuan ini sebagai dasar bagi ibu kapan harus memulai dan teknik yang digunakan untuk melatih anak untuk buang air besar atau kecil. Pengetahuan yang baik akan meningkatkan sikap positif bagi ibu terhadap konsep toilet training sehingga ibu dapat dikatakan siap dalam menerapkan toilet training pada anak. Penjelasan yang baik dari orang tua dan mudah dipahami akan mempengaruhi keberhasilan orang tua dalam mengajarkan toilet training pada anak (Shalahuddin et al., 2018). Berdasar uraian di atas, penelitian ini bertujuan menganalisis hubungan tingkat pengetahuan ibu dengan keberhasilan toilet training pada anak prasekolah di Lamongan.

\section{METODE}

Penelitian deskriptif kuantitatif menggunakan pendekatan cross sectional. Populasinya adalah seluruh ibu yang mempunyai anak prasekolah umur 3-6 tahun di TK Lamongan. Besar sampel dalam penelitian ini sebanyak 40 responden yang diambil melalui teknik simple random sampling. Penelitian ini dilakukan pada bulan Mei-Juli 2019.

Variabel independent dalam penelitian adalah tingkat pengetahuan ibu. Variabel dependent yakni keberhasilan toilet training pada anak prasekolah. Pengumpulan data menggunakan kuesioner pengetahuan toilet training dan kuesioner keberhasilan toilet training. Analisa data dengan univariat dan uji fishers exact test $(p<0.05)$. Penelitian ini lolos kaji etik di Komisi Etik Penelitian Kesehatan Fakultas Keperawatan Universitas Airlangga No. 1676-KEPK. 


\section{HASIL DAN PEMBAHASAN}

Hasil penelitian diperoleh data karakteristik responden, tingkat pengetahuan ibu, keberhasilan toilet training, serta tabulasi silang antara tingkat pengetahun ibu dengan keberhasilan toilet training pada anak prasekolah, seperti pada tabel berikut :

Tabel 1 Distribusi Frekuensi Karakteristik Responden di Lamongan $(n=40)$

\begin{tabular}{|c|c|c|c|c|c|c|}
\hline Karakteristik Responden & Frekuensi (f) & $\begin{array}{c}\text { Persentase } \\
\text { (\%) }\end{array}$ & Mean & Median & $\begin{array}{l}\text { Standar } \\
\text { Deviasi }\end{array}$ & $\begin{array}{l}\text { Minimum - } \\
\text { Maksimum }\end{array}$ \\
\hline Usia Ibu (tahun) & & & 32.15 & & 4.66 & \\
\hline
\end{tabular}

Pendidikan :

\begin{tabular}{lcc} 
a. SD & 6 & 15 \\
b. SMP & 15 & 37.5 \\
c. SMA & 17 & 42.5 \\
d. Sarjana & 2 & 5 \\
\hline
\end{tabular}

Usia Anak (tahun)

Jenis Kelamin Anak :
a. Laki-laki
22
55
b. Perempuan
18
45

Tabel 1 menunjukkan bahwa rata - rata usia ibu adalah 32.15, hampir setengah (42.5\%) responden berada pada kelompok berpendidikan SMA. Nilai median usia anak adalah 5 tahun. Usia termuda 4 tahun dan tertua 6 tahun, serta sebagian besar anak berjenis kelamin laki-laki (55\%).

Tabel 2 Distribusi Frekuensi Tingkat Pengetahuan lbu di Lamongan $(n=40)$

\begin{tabular}{|c|c|c|}
\hline Pengetahuan Ibu tentang Toilet Training & Frekuensi (f) & Persentase (\%) \\
\hline Baik & 33 & 82.5 \\
\hline Kurang & 7 & 17.5 \\
\hline Total & 40 & 100 \\
\hline
\end{tabular}

Pada tabel 2 ditemukan data hampir seluruh (82.5\%) responden memiliki pengetahuan tentang toilet training baik.

Tabel 3. Distribusi Frekuensi Keberhasilan Toilet Training pada Anak Prasekolah di Lamongan ( $n=40)$

\begin{tabular}{lccc}
\hline & Toilet Training & Frekuensi (f) & Persentase (\%) \\
\hline Berhasil & & 36 & 90 \\
\hline Tidak behasil & & 4 & 10 \\
\hline & Total & 40 & 100
\end{tabular}

Hampir seluruh (90\%) responden memiliki anak prasekolah yang berhasil melakukan toilet training.

Tabel 4. Hubungan Tingkat Pengetahuan Ibu dengan Keberhasilan Toilet Training pada Anak Prasekolah di Lamongan $(n=40)$

\begin{tabular}{|c|c|c|c|c|c|c|c|}
\hline \multirow{3}{*}{ Sub variabel } & \multicolumn{4}{|c|}{ Keberhasilan Toilet Training } & \multirow{2}{*}{\multicolumn{2}{|c|}{ Total }} & \multirow{3}{*}{ p. Sig } \\
\hline & \multicolumn{2}{|c|}{ Tidak Berhasil } & \multicolumn{2}{|c|}{ Berhasil } & & & \\
\hline & $\mathrm{n}$ & $\%$ & $\mathbf{n}$ & $\%$ & $\mathbf{n}$ & $\%$ & \\
\hline $\begin{array}{l}\text { Pengetahuan lbu tentang } \\
\text { Toilet Training: }\end{array}$ & & & & & & & 0.013 \\
\hline a. Kurang & 3 & 42.9 & 4 & 57.1 & 7 & 100 & \\
\hline b. Baik & 1 & 3 & 32 & 97 & 33 & 100 & \\
\hline
\end{tabular}

Tabulasi silang pada tabel 4 adalah hampir seluruh (97\%) responden berpengetahuan baik tentang toilet training memiliki anak prasekolah yang berhasil melakukan toilet training dan hampir setengah (42.9\%) 
reponden yang memiliki pengetahuan kurang tentang toilet training memiliki anak prasekolah yang tidak berhasil melakukan toilet training. Hasil uji fishers exact test diperoleh adanya hubungan antara tingkat pengetahuan ibu dengan keberhasilan toilet training pada anak prasekolah di Lamongan $(p=0.013)$.

\section{PEMBAHASAN}

\section{Tingkat Pengetahuan Ibu tentang Toilet Training}

Penelitian menyebutkan bahwa hampir seluruh responden (82.5\%) memiliki pengetahuan tentang toilet training yang baik. Hal ini ditunjang dengan rata-rata usia ibu adalah 32 tahun dan hampir setengah (42.5\%) repsonden memiliki latar belakang pendidikan SMA. Usia responden termasuk dalam usia produktif yang dapat mempengaruhi sesorang untuk cepat menangkap informasi. Hasil yang sama dengan penelitian lain yakni setengah dari ibu mempunyai pengetahuan baik tentang toilet training, serta sebagian kecil ibu memiliki rentang usia 31-40 tahun (Maidartati \& Latif, 2018).

Pengetahuan bisa dipengaruhi oleh tingkat pendidikan. Pendidikan akan mempengaruhi proses belajar seseorang sehingga mudah untuk mendapatkan pengetahuan baru. Pendidikan yang dijalani seorang mempunyai pengaruh terhadap meningkatnya keahlian berpikir, sehingga dapat dikatakan bahwa seorang yang memiliki tingkat pendidikan lebih tinggi harus bisa mengambil keputusan yang lebih rasional. Pengetahuan bisa dipengaruhi oleh usia. Kepercayaan dan kematangan seseorang dalam berfikir dan bekerja akan terlihat dari kecukupan dan kedewasaan usianya (Notoatmodjo, 2012). Usia juga akan mempengaruhi daya tangkap dan pola pikir dalam menerima dan memberikan pengetahuan kepada orang lain (Mubarak, 2011). Semakin muda usia ibu maka semakin besar pengetahuan yang dimiliki, pada usia muda ibu dengan mudah menerima inforrmasi terbaru yang diakses melalui sosial media dan jejaring sosial dari berbagai sumber kemudian dapat diterapkan dengan baik dan benar pada anaknya. Faktor pendidikan sangat mempengaruhi tingkat pengetahuan, ibu berpendidikan rendah memiliki pengetahuan lebih sedikit jika dibandingkan dengan ibu berpendidikan lebih tinggi. Ibu berpendidikan tinggi memiliki pengalaman dan pemahaman yang lebih baik dalam menerima berbagai informasi. Ibu yang berpendidikan tingg memiliki pengetahuan tentang toilet training lebih tinggi dan berhasil menerapkan toilet training pada anaknya dengan benar.

\section{Keberhasilan toilet training}

Hampir seluruh (90\%) responden memiliki anak usia prasekolah berhasil toilet training. Nilai median usia anak adalah 5 tahun. Usia termuda 4 tahun dan tertua 6 tahun. Hal ini sesuai penelitian bahwa sebagian besar (60\%) anak prasekolah berhasil toilet training (Andriyani et al., 2014).

Sfingter anal dan uretra berada di bawah kontrol volunter terjadi antara usia 18 dan 24 bulan. Namun untuk kesiapan anak perlu adanya faktor psikofisiologis. Anak harus memiliki kemampuan mengenali dorongan untuk melepaskan, menahan, dan mengkomunikasikan sensasi ini kepada orang tua. Motivasi dan budaya juga dapat mempengaruhi usia di mana anak-anak menunjukkan kesiapan (Hockenberry et al., 2017). Hal-hal yang menandakan kesiapan anak untuk toilet training adalah bangun dengan keadaan kering dari tidur siang atau semalaman, menyadari keinginan untuk buang air kecil atau buang air besar, mengkomunikasikan kebutuhan, dan menjadi kering setidaknya selama dua jam di siang hari (Wu, 2010).

Keberhasilan toilet training memerlukan persiapan secara fisik, psikologis, dan intelektual. Usia anak dapat mempengaruhi keberhasilan dalam melakukan toilet training, usia anak yang lebih matang dapat mempengaruhi kesiapan fisik untuk melakukan toilet training dengan benar. Anak mampu duduk dan berdiri sendiri. secara psikologis dan intelektual anak mampu konsentrasi dan mengetahui kapan saatnya harus defekasi serta miksi (Hidayat, 2005). 
Toilet training akan berhasil dilakukan bila terdapat beberapa membutuhkan kesiapan secara fisik, psikologis, serta intelektual. Umur anak bisa pengaruhi keberhasilan dalam melaksanakan toilet training, umur anak yang lebih matang bisa pengaruhi kesiapan fisik buat melaksanakan toilet training dengan benar, anak sanggup duduk serta berdiri sendiri, secara psikologis anak sanggup konsentrasi memicu buang air besar/ kecil, dan secara intelektual mengenali kapan saatnya mesti defekasi maupun miksi (Hidayat, 2005).

\section{Hubungan Tingkat Pengetahuan Ibu dengan Keberhasilan Toilet Training pada Anak Prasekolah}

Hampir seluruh (97\%) responden menguasai pengetahuan toilet training dengan baik memiliki anak prasekolah yang berhasil toilet training dan hampir setengah (42.9\%) reponden dengan pengetahuan toilet training kurang memiliki anak prasekolah yang tidak berhasil toilet training. Hasil uji fishers exact test diperoleh hubungan tingkat pengetahuan ibu dengan keberhasilan toilet training pada anak prasekolah di Lamongan. Andriyani et al. (2014) menyebutkan orang tua perlu mengimplementasikan pola asuh campuran, pengetahuan toilet training, dan lingkungan yang baik bagi kesuksesan dalam melatih anak buang air besar/kecil. Penelitian ini menyebutkan adanya hubungan antara pengetahuan $(p=0,012)$ dan lingkungan ( $p=0.002$ ) dengan keberhasilan toilet training pada anak usia prasekolah. Keberhasilan toilet training dipengaruhi oleh keluarga dan anak itu sendiri sehingga tingkat pengetahuan yang kurang dapat menjadi faktor kegagalan toilet training.

Ibu berpengetahuan toilet training baik berpeluang 10 kali mempunyai anak toddler yang mampu toilet training dengan benar karena anak akan sadar dan bersikap positif, serta didukung dengan kesiapan dan keterlibatan orang tua (Istianah et al., 2014). Penelitian lain juga menunjukkan bahwa hampir setengah pengetahuan orang tua cukup dan sebagian besar peran ibu lebih dari cukup memiliki hampir sebagian anak usia 5 tahun yang cukup berhasil dalam melakukan toilet training. Kesuksesan ini dipengaruhi oleh pengetahuan dan peran kedua orang tua. Selain pengetahuan dan peran orang tua diperlukan faktor lain yakni kesiapan anak, persiapan dan perencanaan, lingkungan, serta cara pengajaran toilet training (Youstiana Dwi Rusita, 2015).

Perilaku baru dapat terbentuk bila seseorang mengetahui terlebih dulu menerima stimulus berbentuk objek sehingga memunculkan pengetahuan baru serta berikutnya memunculkan respons batin dalam wujud sikap seorang terhadap objek yang dikenal serta disadari seluruhnya sehingga memunculkan reaksi tindakan sehubungan dengan stimulus yang sudah diketahui (Notoatmodjo, 2012). Pengetahuan ialah salah satu pendorong seorang buat mengadopsi sikap baru. Seseorang yang memiliki kemampuan untuk memahami akan menerapakan pengetahuan tersebut dalam kondisi yang sebenarnya. Pengetahuan ibu tentang toilet training ialah faktor yang mempengaruhi peningkatan kesiapan dan keberhasilan anak dalam toilet training. Perlu adanya pendidikan kesehatan dari puskesmas dan dinas pendidikan tentang toilet training pada orang tua untuk meningkatkan kesiapan dan keberhasilan pelaksanaan toilet training.

\section{SIMPULAN DAN SARAN}

Hasil penelitian diperoleh adanya hubungan tingkat pengetahuan ibu dengan keberhasilan toilet training pada anak prasekolah. Perlu adanya health education dari puskesmas dan dinas pendidikan tentang toilet training pada orang tua untuk meningkatkan kesiapan dan keberhasilan toilet training. Peneliti yang akan datang perlu menyempurnakan penelitian ini dan bisa dijadikan sebagai referensi bagi dengan menggali lagi faktor determinan toilet training. 


\section{DAFTAR PUSTAKA}

Andriyani, S., Ibrahim, K., \& Wulandari, S. (2014). Analisis Faktor-Faktor yang berhubungan Toilet Training pada Anak Prasekolah. Jurnal Keperawatan Padjadjaran, 2(3), 146-153. https://doi.org/10.24198/jkp.v2n3.2

Fithriyana, R., \& Aldopi, A. (2018). Gambaran Pengetahuan Ibu yang Mempunyai Anak Usia 1-3 Tahun tentang Toilet Training di Desa Batu Bersurat Wilayah Kerja Puskesmas XIII Koto Kampar I. Jurnal Pendidikan Anak Usia Dini, 1(2).

Hidayat, A. A. A. (2005). Pengantar Ilmu Keperawatan Anak 1 (Edisi Pert). Salemba Medika.

Hockenberry, M. J., Wilson, D., \& Rodgers, C. C. (2017). Wong's Essentials of Pediatric Nursing (Tenth Edit). Elsevier Inc.

Istianah, Indanah, \& Farida, U. (2014). Pengetahuan Ibu Meningkatkan Kemampuan "Toilet Training" Anak. Jurnal Keperawatan Anak, 2(1), 28-33.

Li, X., Wen, J. G., Xie, H., Wu, X. D., Shen, T., Yang, X. Q., Wang, X. Z., Chen, G. X., Yang, M. F., \& Du, Y. K. (2020). Delayed in toilet training association with pediatric lower urinary tract dysfunction: $A$ systematic review and meta-analysis. Journal of Pediatric Urology, 16(3), 352.e1-352.e8. https://doi.org/10.1016/j.jpurol.2020.02.016

Maghfuroh, L. (2017). Penerapan Metode Visual Auditory dalam Peningkatan Keberhasilan Toilet Training pada Anak Prasekolah. Medical Technology and Public Health Journal, 004, 86-98. http://journal.unusa.ac.id/index.php/mtphj/article/viewFile/459/440

Maidartati, \& Latif, D. D. (2018). Gambaran Pengetahuan Orangtua Tentang Toilet Training pada Anak Usia Toddler di Puskesmas Pasir Kaliki. Jurnal Pengabdian Kepada Masyarakat, 1(1), 7-13. https://doi.org/https://doi.org/10.31294/jabdimas.v1i1.2848.g1852

Mubarak, W. I. (2011). Promosi Kesehatan untuk Kebidanan. Salemba Medika.

Notoatmodjo, S. (2012). Pendidikan dan Perilaku Kesehatan. Rineka Cipta.

Rogers, J. (2013). Daytime Wetting in Children and Acquisition of Bladder Control. Nurs Child Young People, 25(6), 26-33. https://doi.org/10.7748/ncyp2013.07.25.6.26.e195

Shalahuddin, I., Pebrianti, S., \& Maulana, I. (2018). Hubungan Pengetahuan dengan Sikap Ibu dalam Penerapan Toilet Training pada Anak Usia Toddler di Desa Majasari Garut. JUrnal Publikasi Kesehatan Masyarakat Indonesia, 5(2), 59-64. https://doi.org/http://dx.doi.org/10.20527/jpkmi.v5i2.5484

Utami, W., Dwiagung, \& Berliana, D. (2018). Hubungan Pengetahuan Prang Tua (Ibu) tentang Toilet Training terhadap Kejadian Enuresis di TK Dharma Wanita Desa Ngantru Kecamatan Ngasem Kabupaten Bojonegoro Tahun 2017. Asuhan Kesehatan Jurnal IImiah IImu Kebidanan Dan Keperawatan, 8(2), 6-10.

Wu, H.-Y. (2010). Achieving Urinary Continence in Children. Nat Rev Urol, 7(7), 371-377. 
https://doi.org/10.1038/nrurol.2010.78

Youstiana Dwi Rusita, I. A. (2015). Hubungan Pengetahuan dan Peran Orang Tua dengan Keberhasilan Toilet Training pada Anak Usia 5 Tahun di TK Desa Suwaloh Kecamatan Balen Kabupaten Bojonegoro. Jurnal Kebidanan Indonesia, 6(2), 29-35. https://doi.org/10.36419 